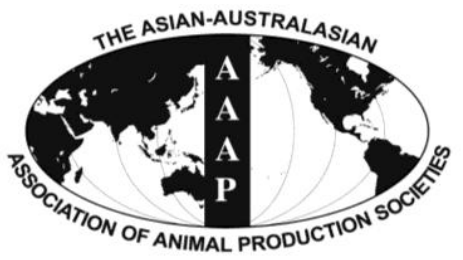

Asian-Aust. J. Anim. Sci.

Vol. 26, No. 1 : 65-71 January 2013

http://dx.doi.org/10.5713/ajas.2011.11408

www.ajas.info

pISSN 1011-2367 elSSN 1976-5517

\title{
Long-term Bias of Internal Markers in Sheep and Goat Digestion Trials
}

\author{
Gleidson Giordano Pinto de Carvalho ${ }^{1,5, *}$, Rasmo Garcia ${ }^{2,5}$, Aureliano José Vieira Pires, \\ Robério Rodrigues Silva ${ }^{3,5}$, Edenio Detmann ${ }^{2,5}$, Ronaldo Lopes Oliveira ${ }^{1,5}$ and Leandro Sampaio Oliveira Ribeiro ${ }^{4}$ \\ ${ }^{1}$ Federal University of Bahia (UFBA), Animal Production Department, Salvador, BA, Brazil
}

\begin{abstract}
Two digestion trials, one with sheep and another with goats, were conducted to evaluate the long-term bias (LTB) of the indigestible dry matter (iDM), indigestible neutral detergent fiber (iNDF) and indigestible acid detergent fiber (iADF) internal markers. The study used eight Santa Inês castrated male sheep (average body weight of $16.6 \mathrm{~kg}$ ) distributed in two $4 \times 4$ Latin squares and eight Saanen castrated male goats (average body weight of $22.6 \mathrm{~kg}$ ) distributed in two $4 \times 4$ Latin squares. The experiments were conducted simultaneously, and the animals were housed in $1.2 \mathrm{~m}^{2}$ individual pens with wood-battened floors equipped with individual feeders and drinkers. The animals received isonitrogenous diets that were offered ad libitum and contained $14 \%$ crude protein and $70 \%$ sugar cane (with $0,0.75,1.5$ or $2.25 \% \mathrm{CaO}$, in natural matter percentage), corrected with $1 \%$ urea and $30 \%$ concentrate. The experiment consisted of four experimental periods of $14 \mathrm{~d}$ each, with the feed, leftovers and feces sampled on the last four days of each period. The marker concentrations in the feed, leftovers and fecal samples were estimated by an in situ ruminal incubation procedure with a duration $240 \mathrm{~h}$. The relationship between the intake and excretion of the markers was obtained by adjusting a simple linear regression model, independently from the treatment (diets) fixed effects and Latin squares. For both the sheep and goats, a complete recovery of the iDM and iNDF markers was observed ( $>0.05$ ), indicating the absence of LTB for these markers. However, the iADF was not completely recovered, exhibiting an LTB of $-9.12 \%(\mathrm{p}<0.05)$ in the sheep evaluation and $-3.02 \%(\mathrm{p}<0.05)$ in the goat evaluation. (Key Words: Fecal Excretion, Intake, Marker Concentration, Ruminal Incubation)
\end{abstract}

\section{INTRODUCTION}

Obtaining digestibility estimations is essential in assessing the energy value of feed, notably via the total digestible nutrients, which allows for the adequate balancing of diets to provide fulfillment of animals maintaining and production demands (Detmann et al., 2007a; Detmann et al., 2008).

When conducting these studies, digestibility estimations are obtained from the fecal excretion of dry matter, which is often performed by collecting feces during a continuous

\footnotetext{
* Corresponding Author: Gleidson Giordano Pinto de Carvalho. Tel: +55-71-32836724, Fax: +55-71-32836718, E-mail: gleidsongiordano@yahoo.com.br

${ }^{2}$ Federal University of Viçosa (UFV), Animal Science Department, Viçosa, MG, Brazil.

${ }^{3}$ Southwest State University of Bahia (UESB), Rural and Animal Technology Department, Itapetinga, BA, Brazil.

${ }^{4}$ Animal Science, Southwest State University of Bahia (UESB), Itapetinga, BA, Brazil.

${ }^{5}$ National Counsel of Technological and Scientific Development (CNPq), Brazil.

Submitted Nov. 7, 2011; Accepted Jan. 4, 2012; Revised Nov. 8, 2012
}

period of $24 \mathrm{~h}$. The search for accurate estimations of the fecal recovery of dry matter using internal markers has been the aim of several studies (Freitas et al., 2002; Oliveira Júnior et al., 2004; Barros et al., 2007). The possibility of using this technique enables digestion trials, improves the practicability of the collection system in obtaining estimations (Silva and Leão, 1979) and minimizes the interference of animal behavior in comparison to total feces quantification procedures (Detmann et al., 2004).

According to Saliba et al. (2008), 'marker' is a term used to name a material used in the qualitative or quantitative estimation of physiological or nutritional phenomena. Within this context, Detmann et al. (2007b) commented that, as they are natural constituents of feed, internal markers naturally exhibit some of the main characteristics of ideal markers, highlighting the absence of the negative influence of both the animal and microbial digestion, with the recovery of feed indigestible fractions as the basis for applying this technique.

The internal markers that are commonly used in digestion trials for obtaining estimations of the fecal dry matter recovery and, subsequently, of digestibility, are the 
indigestible dry matter (iDM), indigestible neutral detergent fiber (iNDF) and indigestible acid detergent fiber (iADF) (Penning and Johnson, 1983; Van Soest, 1994; Detmann et al., 2001; Detmann et al., 2007b).

According to Owens and Hanson (1992), a marker is a reference, a compound used as a chemical (hydrolysis or synthesis) and physical (flux) monitor of aspects of digestion and/or metabolites. Hence, the evaluation of the ideal characteristics of internal markers must focus on questions related to their recovery after being subjected to gastrointestinal events; the accuracy of such a procedure may be assessed by an evaluation of the long-term bias (LTB) (Detmann et al., 2007b). The LTB was defined by Langlands et al. (1963) and cited by Detmann et al. (2007b) as the capacity of the marker to be excreted in a quantity similar to the amount ingested, constituting a characteristic inherent to the marker itself.

Thus, the evaluation of a specific internal marker, when considering that the amount excreted must be the same as that ingested (i.e., a null LTB), will indicate the possibility of using this marker to obtain reliable estimations in digestion assays. However, in the cases in which a marker exhibits a significant LTB (i.e., the amount excreted is different from the amount ingested), your use will compromise the digestion study, as it will not exhibit the characteristic of total fecal recovery, which is a requirement of an ideal marker (Owens and Hanson, 1992; Detmann et al., 2007b).

Therefore, it is clear that the proper choice and use of a determined internal marker in digestion trials depends on the constant observation in the absence of recovery bias (i.e., the LTB), which constitutes a primary characteristic when defining the marker to be adopted (Detmann et al., 2007b).

Two digestion assays, one with sheep and another with goats, were conducted to evaluate the long-term bias of the internal markers of the indigestible dry matter, indigestible neutral detergent fiber and indigestible acid detergent fiber.

\section{MATERIALS AND METHODS}

The experiments were conducted in the Sheep Husbandry and Goat Husbandry Sectors and the Forage and Pasture Laboratory of Southwest State University of Bahia, at the Itapetininga campus, BA, Brazil. Eight Santa Inês castrated male sheep, three months old and with an initial average body weight of $16.6 \mathrm{~kg}$, were distributed in two $4 \times 4$ Latin squares, and eight Saanen castrated male goats, four months old and with initial average body weight of $22.6 \mathrm{~kg}$, were distributed in two $4 \times 4$ Latin squares.

The experiments were conducted simultaneously for 56 $\mathrm{d}$, comprising four experimental periods of $14 \mathrm{~d}$ each, and four different diets were used, containing $70 \%$ sugar cane treated with calcium oxide $(\mathrm{CaO})$ in doses of $0,0.75,1.5$ or
$2.25 \%$ and $30 \%$ in the concentrate (Table 1 ).

The animals were housed in $1.2 \mathrm{~m}^{2}$ individual pens with wood-battened floors equipped with feeders and drinkers that were placed at the front of each pen.

The sugar cane treated with $\mathrm{CaO}$ was offered to the animals $24 \mathrm{~h}$ after being treated. The diets were offered $\mathrm{ad}$ libitum twice a d at 7 am and $3 \mathrm{pm}$ and were adjusted to maintain from 5 to $10 \%$ leftovers of the amount offered; water was always available for the animals.

Both untreated $(0 \% \mathrm{CaO})$ and treated $(0.75,1.5$ or $2.25 \% \mathrm{CaO}$ ) sugar cane were corrected with $1 \%$ urea, on a natural matter basis, when offered to the animals. As the nutritional demands of the animals were similar (NRC, 2006), a single diet was chosen for both species, which was calculated to contain a sufficient nutrient contents to lead to a weight gain of $0.2 \mathrm{~kg} / \mathrm{d}$ (Table 2). The diets were balanced to include approximately $14 \%$ crude protein, and urea was added to the sugar cane by diluting it in water, in which the amount of water was calculated daily, in the proportion of 1 $\mathrm{kg}$ of urea to $4 \mathrm{~L}$ of water. During all of the experiments (before the diets were offered), the soluble sugar content ( ${ }^{\circ} \mathrm{Brix}$ ) of both the natural and $\mathrm{CaO}$-treated sugar cane was monitored using a refractometer and is presented a mean value of $20.3^{\circ}$ Brix.

The $\mathrm{CaO}$ doses added to the sugar cane were measured using a natural matter basis, without previous dilution in water.

For the quantification and evaluation of the voluntary intake, we considered the feed provided between the 10th and 13th $d$ of each experimental period, whereas the leftovers from the 11 th to 14 th $\mathrm{d}$ were considered.

The total feces collection was conducted from the 11th to 14 th $\mathrm{d}$ of each experimental period. The collection in each period, per animal, was performed using a polyethylene canvas, which was installed in the inferior portion of each pen. The total feces were weighed in the morning, and approximately $10 \%$ was removed and stored in a freezer at $-10^{\circ} \mathrm{C}$ for later analysis.

The roughage, concentrate and leftover samples for each animal were dried in an oven with forced-air circulation

Table 1. Percent composition of the concentrate and diet ingredients (\% of the DM)

\begin{tabular}{lcc}
\hline Ingredient & Concentrate & Diet \\
\hline Sugar cane & & \\
Corn meal & - & 70.0 \\
Soybean meal & 55.7 & 16.8 \\
Dicalcium phosphate $_{\text {Mineral mixture }^{2}}$ & 36.2 & 10.9 \\
\hline
\end{tabular}

${ }^{1}$ Sugar cane with different calcium oxide doses $(0,0.75,1.5$ or $2.25 \%$ in $\mathrm{NM})$ and a $1 \%$ urea mixture (\% NM).

${ }^{2}$ Quantity per kg of product: Ca, $120 \mathrm{~g} ; \mathrm{P}, 60 \mathrm{~g} ; \mathrm{S}, 12 \mathrm{~g} ; \mathrm{Mg}, 6 \mathrm{~g} ; \mathrm{Na}, 111$ g; Z, 6,000 mg; Cu, 100 mg; Fe, 1,000 mg; Co, 200 mg; Ni, 42 mg; Mn, $1,400 \mathrm{mg}$. 
Table 2. Chemical composition of the experimental diets

\begin{tabular}{|c|c|c|c|c|}
\hline \multirow{2}{*}{ Item (DM \%) } & \multicolumn{4}{|c|}{$\mathrm{CaO}$ doses on sugar cane ${ }^{2}$} \\
\hline & 0 & 0.75 & 1.5 & 2.25 \\
\hline Dry matter & 45.8 & 46.1 & 46.9 & 47.8 \\
\hline Potentially digestible dry matter & 78.8 & 78.2 & 81.2 & 84.3 \\
\hline Indigestible dry matter & 25.4 & 26.5 & 22.8 & 19.6 \\
\hline Organic matter & 94.7 & 93.1 & 91.6 & 90.3 \\
\hline Crude protein & 14.8 & 14.8 & 14.7 & 14.9 \\
\hline Neutral detergent fiber & 43.7 & 45.0 & 42.2 & 39.6 \\
\hline Neutral detergent fiber (ap) ${ }^{1}$ & 39.5 & 41.0 & 37.8 & 35.1 \\
\hline Indigestible neutral detergent fiber & 22.4 & 23.1 & 19.9 & 16.8 \\
\hline Potentially digestible neutral detergent fiber & 21.3 & 21.9 & 22.3 & 22.9 \\
\hline Non fibrous carbohydrate (ap) ${ }^{1}$ & 35.8 & 33.4 & 35.5 & 37.0 \\
\hline Acid detergent fiber & 28.4 & 29.7 & 26.5 & 26.2 \\
\hline Indigestible acid detergent fiber & 18.1 & 17.8 & 17.4 & 12.9 \\
\hline Lignin & 5.4 & 5.3 & 4.6 & 4.3 \\
\hline
\end{tabular}

${ }^{1}$ Values corrected for ash and protein. ${ }^{2}$ Sugar cane added with $1 \%$ urea and $\mathrm{CaO}$ doses as a percentage of the natural matter.

$\left(60^{\circ} \mathrm{C}\right)$ and processed in a knife mill (a sieve with a $1-\mathrm{mm}$ opening).

The dry matter (DM), organic matter (OM), crude protein $(\mathrm{CP})$, neutral detergent fiber (NDF), acid detergent fiber (ADF) and lignin $\left(\mathrm{H}_{2} \mathrm{SO}_{4} 72 \% \mathrm{w} / \mathrm{w}\right)$ content of the diets were determined according to the procedure described by Silva and Queiroz (2002). The neutral detergent fiber, with corrections for the ash and protein (NDFap) contents, was determined according to the recommendations of Licitra et al. (1996) and Mertens (2002).

The estimation of the potentially digestible neutral detergent fiber (NDFpD) and potentially digestible dry matter (DMpD) contents were obtained according to Paulino et al. (2006), whereas the non-fibrous carbohydrate, with corrections for the ash and protein (NFCap) contents, was calculated using the following equation proposed by Hall (2003):

\section{NFCap $=(100-\%$ NDFap-\% CP-\% EE-\% ash}

For the indigestible dry matter (iDM), indigestible NDF (iNDF) and indigestible ADF (iADF) content estimations, samples of approximately $1 \mathrm{~g}$ of the provided feed (sugar cane and concentrate), leftovers and feces were incubated for $240 \mathrm{~h}$, in double determinations $\left(20 \mathrm{mg} \mathrm{DM} / \mathrm{cm}^{2}\right)$, in previously weighed, nonwoven tissue $\left(100 \mathrm{~g} / \mathrm{m}^{2}\right)$ bags inserted into the rumen of two crossbreed steers receiving a mixed diet. After this period, the bags were removed and washed with running water, and the material remaining after the incubation was dried in an oven with forced-air circulation at $60^{\circ} \mathrm{C}$ for $72 \mathrm{~h}$. The material was then desiccated and weighed; the residue obtained was considered to be the iDM. The bags were then placed in plastic pots, and $50 \mathrm{ml}$ of neutral detergent was added per bag. The bags were boiled in the neutral detergent for one hour, washed with hot water and acetone, dried and weighed, as above; this residue was considered to be the iNDF. This same procedure was then performed using an acid detergent, which provided the iADF value. The mean concentrations of the markers in the feed, leftovers and feces samples are presented in Table 3.

The procedure for comparing the amounts of each marker ingested and excreted was performed independently from the fixed effects of the treatments and Latin squares by adjusting a simple linear regression model of the estimations of the excretion over intake, while testing the regression parameter estimations under the following hypotheses:

$$
\begin{array}{ll}
H_{0}: \beta_{0}=0 & H_{0}: \beta_{1}=1 \\
H_{\mathrm{a}}: \beta_{0} \neq 0 & H_{\mathrm{a}}: \beta_{1} \neq 1
\end{array}
$$

It was concluded that the intake and excretion were similar when neither of the null hypotheses were rejected, that is, there was no recovery bias or long-term bias. However, when a null hypothesis was rejected, the longterm bias was estimated according to the following equation proposed by Detmann et al. (2005):

Table 3. Mean concentrations ( $\mathrm{g} / \mathrm{kg}$ of dry matter) of the internal markers in the feed, leftovers and feces

\begin{tabular}{lrrr}
\hline Item & iDM & iNDF $^{2}$ & iADF $^{3}$ \\
\hline Sugar cane & 317.2 & 285.9 & 232.6 \\
Concentrate & 45.3 & 17.7 & 9.7 \\
Sheep & & & \\
$\quad$ Leftovers & 400.3 & 366.6 & 309.7 \\
$\quad$ Feces & 602.3 & 512.0 & 387.0 \\
Goats & & & \\
$\quad$ Leftovers & 390.4 & 354.8 & 297.5 \\
$\quad$ Feces & 592.8 & 499.8 & 400.9 \\
\hline
\end{tabular}

${ }^{1}$ Indigestible dry matter (iDM).

${ }^{2}$ Indigestible neutral detergent fiber (iNDF).

${ }^{3}$ Indigestible acid detergent fiber (iADF). 
Table 4. Relationships of the intake and excretion of the internal markers in sheep and goats

\begin{tabular}{|c|c|c|c|c|c|c|c|}
\hline \multirow{3}{*}{ Marker $^{\mathrm{a}}$} & \multirow{2}{*}{\multicolumn{2}{|c|}{ Mean $(g / d)$}} & \multirow{3}{*}{$\mathrm{VC}(\%)$} & \multicolumn{4}{|c|}{ Linear regression } \\
\hline & & & & \multicolumn{2}{|c|}{ Intercept } & \multicolumn{2}{|c|}{ Slope coefficient } \\
\hline & Intake & Excretion & & Estimation & p-value ${ }^{b}$ & Estimation & p-value ${ }^{c}$ \\
\hline \multicolumn{8}{|c|}{ Sheep trial } \\
\hline iDM & 115.4 & 112.2 & 8.26 & 0.0271 & 0.1312 & 0.7380 & 0.1355 \\
\hline iNDF & 99.2 & 97.2 & 12.56 & 0.0164 & 0.1162 & 0.8141 & 0.0710 \\
\hline iADF & 83.8 & 79.3 & 19.85 & 0.0423 & 0.0604 & 0.3706 & 0.0001 \\
\hline \multicolumn{8}{|l|}{ Goat trial } \\
\hline iDM & 177.9 & 177.1 & 13.9 & 0.0273 & 0.2026 & 0.8425 & 0.1817 \\
\hline iNDF & 152.4 & 148.8 & 13.7 & 0.0263 & 0.1455 & 0.8039 & 0.0933 \\
\hline iADF & 121.8 & 120.4 & 21.2 & 0.0363 & 0.0547 & 0.6908 & 0.0403 \\
\hline
\end{tabular}

${ }^{\mathrm{a}}$ Indigestible dry matter (iDM), indigestible neutral detergent fiber (iNDF) and indigestible acid detergent fiber (iADF).

${ }^{\mathrm{b}} \mathrm{H}_{0}: \beta_{0}=0 ; \mathrm{H}_{\mathrm{a}}: \beta_{0} \neq 0 .{ }^{\mathrm{c}} \mathrm{H}_{0}: \beta_{1}=1 ; \mathrm{H}_{\mathrm{a}}: \beta_{1} \neq 1$.

$$
\operatorname{LTB}(\%)=(\hat{\beta}-1) \times 100
$$

where $\hat{\beta}=$ the linear slope coefficient for the relationship between the iADF intake and excretion, assuming a null intercept.

\section{RESULTS AND DISCUSSION}

The mean estimations of the intake and excretion of the markers, variation coefficients and regression study parameters are provided in Table 4 . For both the sheep and goat digestion trials, neither of the null hypotheses were rejected $(\mathrm{p}>0.05)$ for the indigestible dry matter (iDM) and indigestible neutral detergent fiber (iNDF) internal markers, indicating their complete fecal recovery and a nonsignificant long-term bias (LTB) (Table 4). This result is depicted graphically in Figure 1, 2, 3 and 4, which correspond to the relationship between the iDM and iNDF intake and excretion (for sheep and goats), respectively, and may be identified by the dispersion of the points over the equality lines $(y=x)$ and by the proximity of the least-

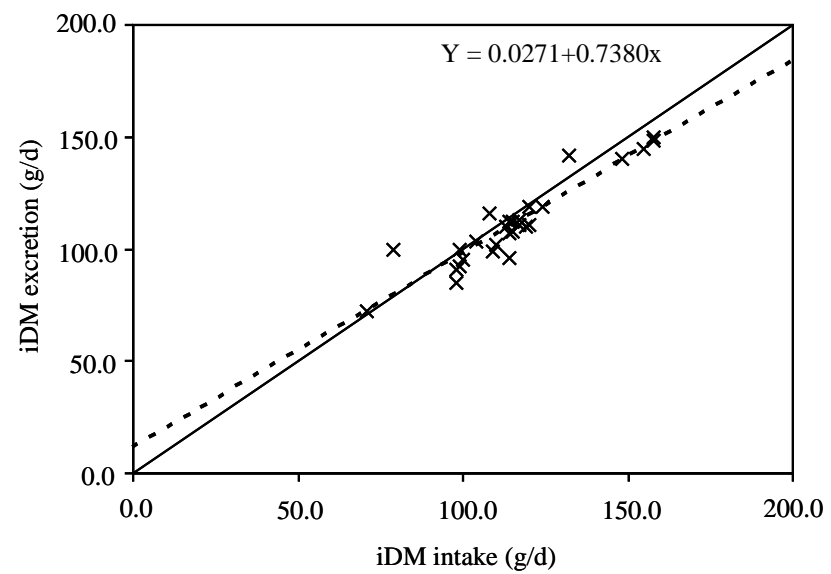

Figure 1. Relationship between the intake and fecal excretion of indigestible dry matter (iDM) in sheep (the dashed line corresponds to the least-squares line). squares line to the equality line $(\mathrm{y}=\mathrm{x})$.

As for the indigestible acid detergent fiber (iADF) marker, in both of the experiments, a rejection of the null hypotheses associated with the intercept was not observed ( $p>0.05$ ); however, the rejection of the null hypotheses associated with the slope coefficient was observed $(\mathrm{p}<0.05)$ (Table 4) This result indicated the presence of an LTB in the iADF excretion estimations, which was estimated according to the equation proposed by Detmann et al. (2005), and produced an LTB or recovery bias of $-9.12 \%$ in the sheep trial and $-3.02 \%$ in the goat trial (Table 5). This behavior of the iADF is illustrated graphically in Figure 5 and 6 , in which an accentuated slope of the least-squares line is observed when compared to the equality line $(y=x)$, which is possibly related to a higher dispersion of the points over the equality line.

According to Detmann et al. (2007b), failure in the fecal recovery of a marker is commonly represented by its disappearance along the digestive tract, implying a negative LTB. Comparing this information with the results of the iADF in the present study, which exhibited a significant $(p<0.05)$ and negative LTB for both of the digestion trials,

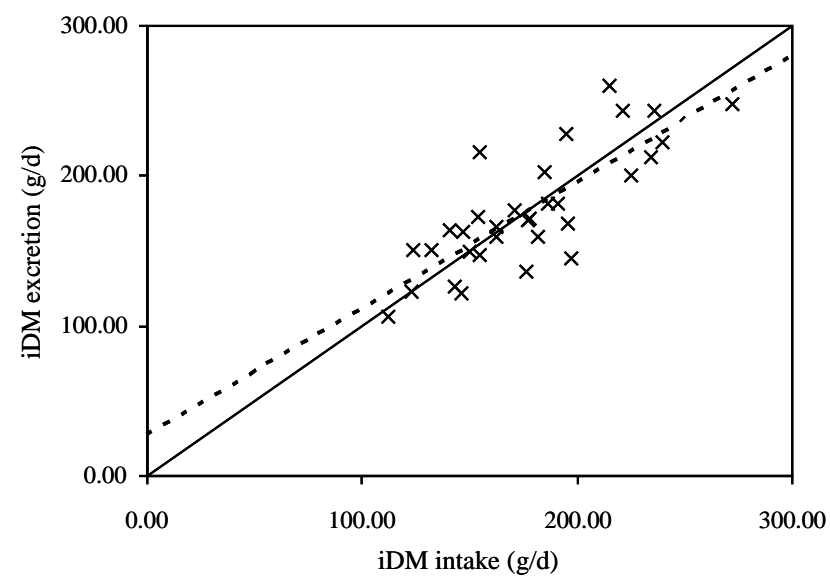

Figure 2. Relationship between the intake and fecal excretion of indigestible dry matter (iDM) in goats (the dashed line corresponds to the least-squares line). 


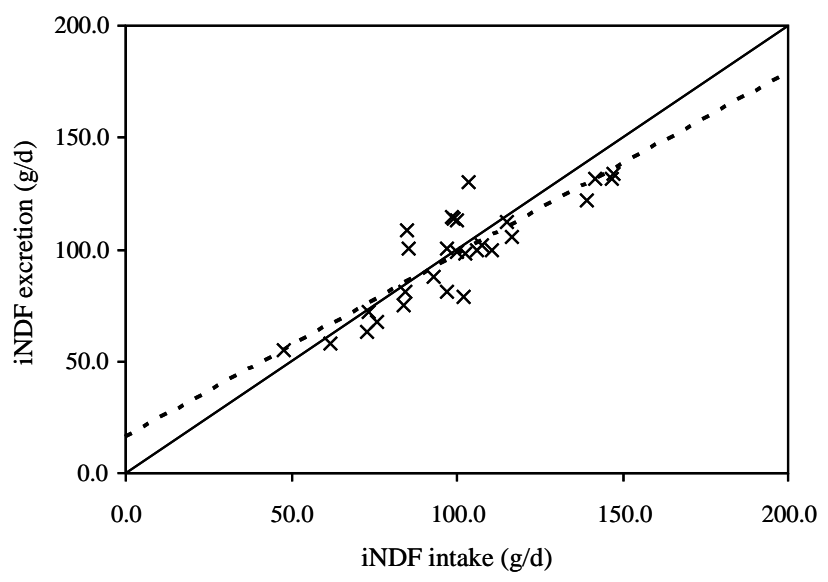

Figure 3. Relationship between the intake and fecal excretion of indigestible neutral detergent fiber (iNDF) in sheeps (the dashed line corresponds to the least-squares line).

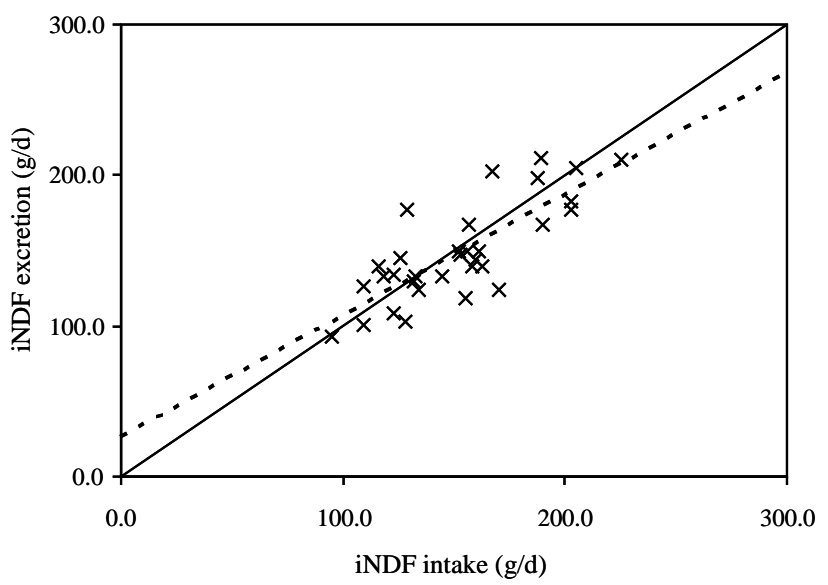

Figure 4. Relationship between the intake and fecal excretion of indigestible neutral detergent fiber (iNDF) in goats (the dashed line corresponds to the least-squares line).

we suggest that this marker is inefficient for the estimation of the fecal excretion of dry matter in digestibility studies with feedlot animals, as the behavior observed for the iADF indicated an inferior fecal recovery of the total ingested for both sheep $(\mathrm{p}<0.01)$ and goats $(\mathrm{p}<0.05)($ Table 4$)$. These results are in accordance with those of Detmann et al. (2007b), who evaluated the LTB of iDM, iNDF and iADF internal markers in a digestion trial with ruminants (sheep) and observed a non-significant LTB for the iDM and iNDF

Table 5. Long-term bias (LTB) estimations for the indigestible neutral detergent fiber (iADF) marker used in digestion trials with sheep and goats

\begin{tabular}{ll}
\hline Marker & $\mathrm{LTB}^{1}(\%)$ \\
\hline iADF (Sheep trial) & -9.12 \\
iADF (Goats trial) & -3.02 \\
\hline Due to the rejection of the hypothesis associated with the slope \\
coefficient for the relationship between the iADF intake and fecal \\
excretion (Table 3), the LTB was estimated according to the equation \\
proposed by Detmann et al. $(2005): \operatorname{LTB}(\%)=(\hat{\beta}-1) \times 100$.
\end{tabular}

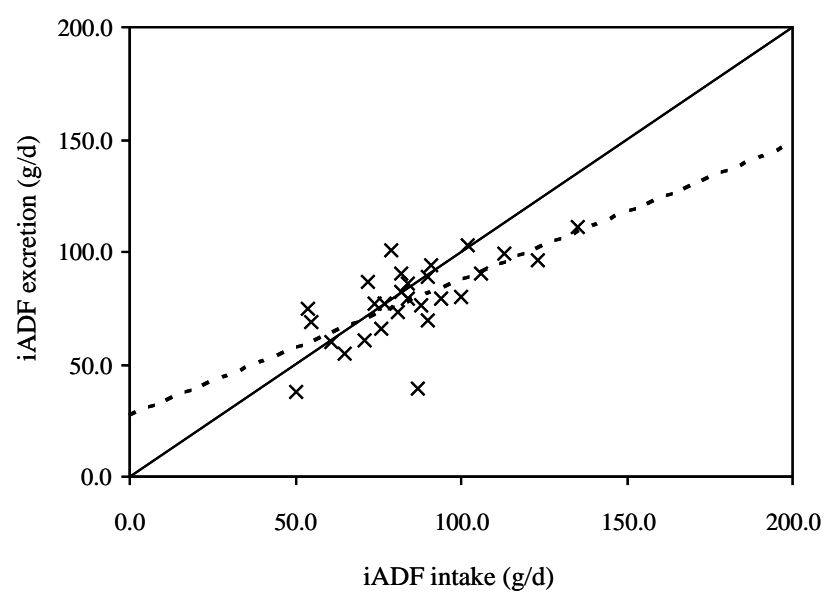

Figure 5. Relationship between the intake and fecal excretion of indigestible acid detergent fiber (iADF) in sheep (the dashed line corresponds to the least-squares line).

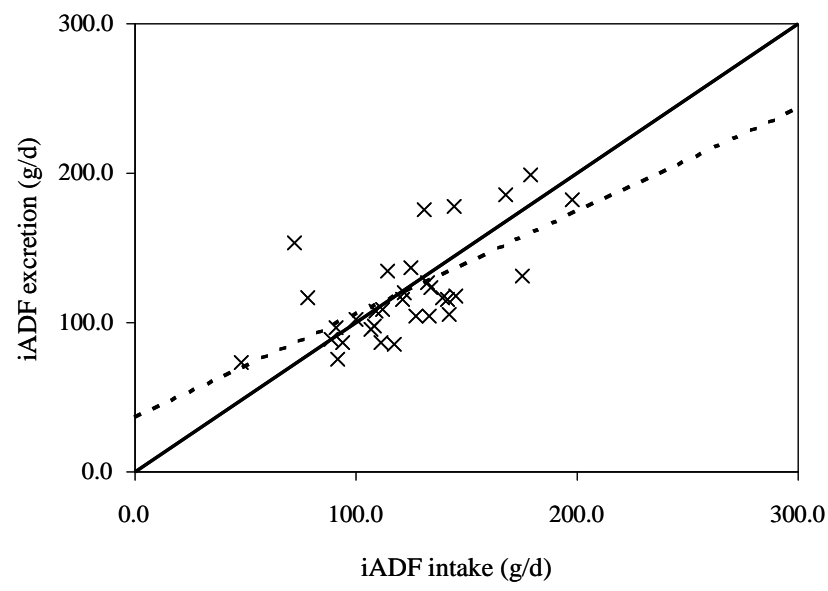

Figure 6. Relationship between the intake and fecal excretion of indigestible acid detergent fiber (iADF) in goats (the dashed line corresponds to the least-squares line).

and a significant LTB for the relationship between the intake and excretion of the iADF.

The quantification of the ADF was obtained by a sequential method; thus, a significant LTB for the iADF marker may, in part, be supported by the arguments presented by Detmann et al. (2001), who reported on the possible accumulation of error, as the result for the iADF is the last step in the procedure and may reflect on inexact estimations of its concentration. Similarly, Detmann et al. (2004) attributed the major limiting factor of using indigestible components as markers to the analytical procedures used for estimating their concentration, particularly in the differences in the evaluation of the feed and feces due to the variations in the physical structure of the particles and the different influences of the drying processes. Detmann et al. (2007b) added that, in addition to errors arising from the non-standardization of analytical methods, the lower iADF concentrations in the feed, leftovers and samples, as compared to the iDM and iNDF 
markers, may also contribute to an increase in systemic errors, which reduce the efficiency of using the iADF as a marker in the indirect estimation of digestibility in ruminants.

The presence of a significant and negative LTB, as observed for the relationship between the iADF intake and excretion values, indicates a low accuracy of this marker for estimating digestibility parameters, as a secondary evaluation of the suitability of using this marker would lead to an overestimation of the fecal excretion of dry matter, with a concomitant underestimation of the digestibility coefficients. This fact is confirmed by the results presented by Pina et al. (2006), who studied the iNDF and iADF internal markers and observed lower apparent digestibility coefficients when the iADF was used as a marker, as compared to the iNDF. It should be emphasized that the authors observed a higher fecal excretion of dry matter when the iADF was used, which is in accordance with the assumptions of the present study. These assumptions regarding the use of the $\mathrm{iADF}$ are also in accordance with the results presented by Zeoula et al. (2002), who evaluated the fecal recovery of internal markers in digestion trials of ruminants and reported a total recovery of the iNDF and an incomplete recovery of the iADF in feces. As a result of the incomplete iADF recovery in feces, the authors observed an overestimation of the fecal excretion of dry matter when using this marker.

Although internal markers, namely, the iDM, iNDF and iADF, should be primarily evaluated by an LTB or recovery bias before they are used in estimating the fecal excretion of dry matter (Detmann et al., 2007b), many studies using the direct evaluation of these markers in fecal excretion and digestibility estimations have been conducted and continue to be the aim of much research. In some of these studies (Saliba et al., 1999; Ítavo et al., 2002; Dias et al., 2008), the authors have suggested that using the iADF as a marker is better than the iNDF in the estimation of fecal excretion and digestibility. In contrast, some studies (Detmann et al., 2001; Pina et al., 2006; Cabral et al., 2008) have recommended using the iNDF instead of the iADF for obtaining such estimations, whereas other studies (Berchielli et al., 1998; 2000) have recommended using neither the iNDF or iADF.

Clearly, the results for ideal markers in the diet evaluation systems in ruminant animals are contradictory and indicate the necessity of further investigation for an appropriate conclusion; indeed, the effects on the procedure due to the analytical and collection methods and digestive tract dynamics need to be better understood. It should be emphasized, however, that some of the conclusions obtained in these marker experiments were established considering only the precision of the marker and not its accuracy, as the collection of total feces was not conducted in some of these studies, which does not allow definitive conclusions. According to Cabral et al. (2008), the evaluation of a marker using only its precision restricts the conclusion inference space, leading to false results.

\section{CONCLUSIONS}

For both sheep and goats, the indigestible dry matter and indigestible neutral detergent fiber internal markers exhibited full fecal recovery and, thus, are indicated for use in digestion trials for obtaining estimations of the fecal excretion of dry matter and digestibility coefficients.

The indigestible acid detergent fiber internal marker exhibits a fecal recovery bias, which compromises its accuracy as a marker for digestion trials in sheep and goats. The long-term bias estimated when using the indigestible acid detergent fiber was $-9.12 \%$ for sheep and $-3.02 \%$ for goats.

\section{REFERENCES}

Barros, E. E. L., C. A. A. Fontes, E. Detmann, R. A. M. Vieira, L. T. Henriques and E. G. Ribeiro. 2007. Evaluation of excretion patterns of internal markers and chromium oxide in digestion assays with ruminants. Rev. Bras. Zootec. 36:2102-2108.

Berchielli, T. T., P. Andrade and C. L. Furlan. 2000. Evaluation of internal markers in digestibility assay. Rev. Bras. Zootec. 29:830-833.

Berchielli, T. T., N. M. Rodriguez, E. Osório Neto and S. S. Rocha. 1998. Comparison of indicators to measure solid-phase flow of dry matter and organic matter in the duodenum. Arq. Bras. Med. Vet. Zoo. 50:147-152.

Cabral, L. S., S. C. Valadares Filho, E. Detmann, J. T. Zervoudakis, A. L. Souza and R. G. Veloso. 2008. Evaluation of indicators in the estimation of fecal excretion and digestibility in ruminants. Ver. Bras. Saúde Prod. An. 9:29-34.

Detmann, E., A. L. Souza, R. Garcia, S. C. Valadares Filho, L. S. Cabral and J. T. Zervoudakis. 2007b. Evaluation of the "vice of time" of internal markers in digestion trial with ruminants. Arq. Bras. Med. Vet. Zoo. 59:182-188.

Detmann, E., M. F. Paulino and S. C. Valadares Filho. 2008. Nutritional evaluation of foods or diets? A conceptual approach. In: Proceedings of Symposium Of Livestock Production Cutting, Minas Gerais, Viçosa. 6:21-51.

Detmann, E., M. F. Paulino, J. T. Zervoudakis, S. C. Valadares Filho, R. F. Euclydes, R. P. Lana and D. S. Queiroz. 2001. Chrome and internal indicators in determining the consumption of steers supplemented at pasture. Rev. Bras. Zootec. 30:1600-1609.

Detmann, E., M. F. Paulino, L. S. Cabral, S. C. Valadares Filho, P. R. Cecon, J. T. Zervoudakis, R. P. Lana, M. I. Leão and A. J. N. Melo. 2005. Simulation and validation of parameters of digestive kinetics in steers supplemented at pasture, through the system in vitro gas production. Rev. Bras. Zootec. 34:21122122 . 
Detmann, E., S. C. Valadares Filho, L. T. Henriques, D. S. Pina, M. F. Paulino, A. L. R. Magalhães, D. M. Figueiredo, M. O. Porto and M. L. Chizzotti. 2007a. Reparametrization of the model based on the law of surface to predict digestible fraction of neutral detergent fiber in Brazilian conditions. Rev. Bras. Zootec. 36:155-164.

Detmann, E., S. C. Valadares Filho, M. F. Paulino, J. T. Zervoudakis and L. S. Cabral. 2004. Evaluation of technical indicators in the estimation of consumption by grazing ruminants. Cadernos Técnicos de Veterinária e Zootecnia 45: 40-57.

Dias, M., M. I. Leão, E. Detmann, S. C. Valadares Filho, A. M. Vasconcelos, S. M. Souza, M. F. Paulino and T. B. Murça. 2008. Techniques for estimate of digestion and microbial production in bovine. Rev. Bras. Zootec. 37:504-512.

Freitas, D., T. T. Berchielli, R. N. Silveira, J. P. G. Soares, J. J. R. Fernandes and A. V. Pires. 2002. Duodenal flow and fecal output of dry matter and organic matter estimated by indicators. Rev. Bras. Zootec. 31:1521-1530.

Hall, M. B. 2003. Challenges with non-fiber carbohydrate methods. J. Anim. Sci. 81:3226-3232.

Ítavo, L. C. V., S. C. Valadares Filho, F. F. Silva, R. F. D. Valadares, M. F. Paulino, C. C. B. F. Itavo and E. H. B. K. Moraes. 2002. Comparison of markers and collection methodology for fecal production and digesta flow estimates in bovine. Rev. Bras. Zootec. 31:1833-1839.

Licitra, G., T. M. Hernandez and P. J. Van Soest. 1996. Standardization of procedures for nitrogen fracionation of ruminant feeds. Anim. Feed Sci. Technol. 57:347-358.

Mertens, D. R. 2002. Gravimetric determination of amylasetreated neutral detergent fiber in feeds with refluxing in beakers or crucibles: collaborative study. J. AOAC Int. 85:1217-1240.

NRC (National Research Council). 2006. Nutrient requirements of small ruminants. Washington: National Academy Press, 2006.
Oliveira Júnior, R. C., A. V. Pires, J. J. R. Fernandes, I. Susin, F. A. P. Santos, V. F. Nascimento Filho and R. C. Araujo. 2004. Comparison of markers for estimating nutrient digestibility in high grain beef cattle diets varying nitrogen sources. Rev. Bras. Zootec. 33:749-758.

Owens, F. N. and, C. F. Hanson. 1992. External and internal markers for appraising site and extent of digestion in ruminants. J. Dairy Sci. 75:2605-2617.

Paulino, M. F., E. Detmann and S. C. Valadares Filho. 2006. Supplementation in animal pasture: energy or protein? In: Proceedingf of Symposium On Strategic Management Of Pasture, Minas Gerais, Viçosa. 1:359-392.

Penning, P. D. and R. H. Johnson. 1983. The use of internal markers to estimate herbage digestibility and intake. 2. Indigestible acid detergent fiber. J. Agric. Sci. 100:133-138.

Pina, D. S., S. C. Valadares Filho, E. Detmann, R. F. D. Valadares, M. S. Campos, K. A. K. Moraes, A. S. Oliveira and M. L. Paixão. 2006. Comparison of internal markers and extent of total fecal collection to estimate nutrient digestibility and energy value of feeds on dairy cows fed different protein sources. Rev. Bras. Zootec. 35:2461-2468.

Saliba, E. O. S., N. M. Rodriguez, L. C. Gonçalves, S. A. L. Morais, D. Piló-Veloso. 2002. Lignin isolated from corn husks used with indicator in digestibility trials. Comparative study. Arquivo Brasileiro de Medicina Veterinária e Zootecnia, 54:52-56.

Silva, D. J. and A. C. Queiroz. 2002. Food analysis: chemical and biological methods. Viçosa. 2th ed. p. 235.

Silva, J. F. C. and M. I. Leão 1994. Fundamentals of nutrition of ruminants. Piracicaba. 1 th ed. p. 380

Van Soest, P. J. 1994. Nutritional ecology of the ruminant. Ithaca: Cornell University Press.

Zeoula, L. M., I. N. Prado, P. H. M. Dian, L. J. V. Geron, S. F. Caldas Neto, E. M. Maeda, P. D. P. Peron, J. A. Marques and A. J. S. Falcão. 2002. Fecal recovery of internal markers in assay with ruminants. Rev. Bras. Zootec. 31:1865-1874. 